\title{
Transfer of Streptococcus faecalis and Streptococcus faecium to the Genus Enterococcus nom. rev. as Enterococcus faecalis comb. nov. and Enterococcus faecium comb. nov.
}

\author{
KARL H. SCHLEIFER* AND RENATE KILPPER-BÄLZ \\ Lehrstuhl für Mikrobiologie, Technische Universität München, D-8000 München 2, Federal Republic of Germany
}

\begin{abstract}
The results of deoxyribonucleic acid-deoxyribonucleic acid and deoxyribonucleic acid-ribosomal ribonucleic acid hybridization studies demonstrated that Streptococcus faecalis and Streptococcus faecium are distantly related to the non-enterococcal streptococci (Streptococcus bovis and Streptococcus equinus) of serological group D and to other streptococci. On the basis of our results and those of previous studies, we propose that $S$. faecalis and $S$. faecium be transferred to the genus Enterococcus (ex Thiercelin and Jouhaud) nom. rev. as Enterococcus faecalis (Andrewes and Horder) comb. nov. and Enterococcus faecium (Orla-Jensen) comb. nov., respectively. A description of the genus Enterococcus nom. rev. and emended descriptions of E. faecalis and E. faecium are given.
\end{abstract}

The streptococci belonging to serological group D can be divided into two physiologically different groups. Streptococcus faecalis and Streptococcus faecium were placed in the enterococcus division of the streptococci, whereas Streptococcus bovis and Streptococcus equinus were placed in the viridans division by Sherman (21). Kalina proposed (9) that Streptococcus faecalis and Streptococcus faecium should be transferred to the genus "Enterococcus." This distinction between the enterococci and Streptococcus bovis, Streptococcus equinus, and other streptococci has also been demonstrated by comparative biochemical (25) and immunological $(14,15)$ studies. More recently, nucleic acid studies $(7,12)$ have confirmed that Streptococcus faecalis and Streptococcus faecium are only distantly related to Streptococcus bovis and Streptococcus equinus. In particular, deoxyribonucleic acid (DNA)-ribosomal ribonucleic acid (rRNA) homology studies (12) and comparative oligonucleotide cataloging of $16 \mathrm{~S}$ rRNA (E. Seewaldt, Ph.D. thesis, Technische Universität München, Munich, Federal Republic of Germany, 1982) have indicated that the enterococcal and non-enterococcal group D streptococci belong to different genera. In this paper we extend these studies, and on the basis of the data we propose that Streptococcus faecalis and Streptococcus faecium be transferred to the genus Enterococcus (ex Thiercelin and Jouhaud) nom. rev. (22).

\section{MATERIALS AND METHODS}

The test strains which we used are listed in Table 1. The streptococci were cultivated in CASO-bouillon medium (E. Merck AG, Darmstadt, Germany) without aeration at $34^{\circ} \mathrm{C}$. Staphylococcus sciuri and Escherichia coli were grown in shake flasks containing glucose-peptone-yeast extract broth (13) at $34^{\circ} \mathrm{C}$. All strains were harvested in the exponential phase. The procedures used to prepare cell walls and determine the peptidoglycan types have been described previously $(19,20)$. Isolation of DNA and rRNA and nucleic acid hybridization experiments were carried out as described previously (11-13). The stability of DNA-rRNA hybrids is expressed by their melting temperatures. DNA base compositions were determined by thermal denaturation (16), using a Gilford model 2600 spectrophotometer. DNA from Escherichia coli $\mathrm{K}-12$ was used as the standard. The guanine-pluscytosine $(\mathrm{G}+\mathrm{C})$ contents were calculated by the method of

\footnotetext{
* Corresponding author.
}

De Ley (4) and were corrected to the value for the reference Escherichia coli K-12 DNA.

\section{RESULTS AND DISCUSSION}

The DNA base compositions, serological groups, and peptidoglycan types of the test strains are shown in Table 1. The enterococci studied (Streptococcus faecalis, Streptococcus faecium, "Streptococcus avium", "Streptococcus durans", and "Streptococcus casseliflavus") had DNA $\mathrm{G}+\mathrm{C}$ contents in the range from 37 to $43 \mathrm{~mol} \%$. These data are in good agreement with the data given recently by Farrow et al. (7); however, they are about 1 to 2 mol\% lower than the values reported by Kilpper-Bälz et al. (12), who used a value for the base composition of the reference DNA that was too high (53 instead of $51.7 \mathrm{~mol} \%$ ).

Streptococcus faecalis and its subspecies possess the Lys$\mathrm{Ala}_{2-3}$ peptidoglycan type and differ in this respect from all of the other enterococci, which contain the Lys-D-Asp peptidoglycan type $(8,12,20)$. The results of previous studies, in particular those of Kilpper-Bälz et al. (12) and Seewaldt (Ph.D. thesis), clearly indicated that the enterococci are not closely related to the other streptococci. In this study ${ }^{3} \mathrm{H}$ labeled 23S rRNAs from Streptococcus faecalis DSM 20376 and "Streptococcus avium" DSM 20063 were hybridized with filter-bound DNAs from strains of Streptococcus faecalis, Streptococcus faecium, "Streptococcus durans", "Streptococcus casseliflavus", and some other streptococci (Table 2). Our results indicate that all of the enterococci examined share high rRNA homology and are only remotely related to other streptococci (Table 2).

The results of our DNA-DNA hybridization studies (Fig. 1) confirm the separate species status of Streptococcus faecalis and Streptococcus faecium $(7,12)$. All strains of Streptococcus faecalis were closely related (DNA homology values, $88 \%$ ) regardless of their subspecies status. The Streptococcus faecium strains showed low but still significant levels of DNA homology (ca. 18\%) with Streptococcus faecalis. The very low levels of DNA homology $(<9 \%)$ between Streptococcus faecalis and Streptococcus faecium strains and other streptococci are consistent with the DNArRNA hybridization data (12). Three strains of Streptococcus faecium shared a lower level of DNA homology (40\%) with the type strain of Streptococcus faecium (Fig. 1) and may represent a distinct species or at least a subspecies. The 
TABLE 1. Bacterial strains used and their serological groups, DNA base contents, and peptidoglycan types

\begin{tabular}{|c|c|c|c|}
\hline Strain & $\begin{array}{l}\text { Lance- } \\
\text { field } \\
\text { group }\end{array}$ & $\begin{array}{l}\mathrm{G}+\mathrm{C} \\
\text { content } \\
\text { (mol\%) }\end{array}$ & $\begin{array}{l}\text { Type of } \\
\text { peptido- } \\
\text { glycan }\end{array}$ \\
\hline "Streptococcus avium" DSM 20063 & $\mathrm{D}+\mathrm{Q}$ & 39.2 & Lys-D-Asp \\
\hline "Streptococcus bovis" DSM 20480 Ta & $\mathrm{D}$ & 38.0 & $\begin{array}{l}\text { Lys-Thr- } \\
\text { Ala(Ser) }\end{array}$ \\
\hline $\begin{array}{l}\text { "Streptococcus casseliflavus" } \\
\text { CCM } 2478\end{array}$ & $\mathrm{D}$ & 43.7 & Lys-D-Asp \\
\hline $\begin{array}{l}\text { "Streptococcus casseliflavus" } \\
\text { CCM } 2479\end{array}$ & $\mathrm{D}$ & 44.6 & Lys-D-As \\
\hline "Streptococcus durans" CCM 5612 & $\mathrm{D}$ & 39.0 & Lys-D-Asp \\
\hline "Streptococcus durans" Kiel 27382 & $\mathrm{D}$ & 38.2 & Lys-D-Asp \\
\hline $\begin{array}{l}\text { "Streptococcus faecalis" DSM } \\
20478^{\mathrm{T}}\end{array}$ & $\mathrm{D}$ & 38.6 & Lys-Ala \\
\hline $\begin{array}{l}\text { "Streptococcus faecalis subsp. fae- } \\
\text { calis" DSM } 20376\end{array}$ & $\mathrm{D}$ & 37.7 & Lys-Ala $2-3$ \\
\hline $\begin{array}{l}\text { "Streptococcus faecalis subsp. fae- } \\
\text { calis" Kiel } 7067\end{array}$ & $\mathrm{D}$ & 37.7 & Lys-Ala $2-3$ \\
\hline $\begin{array}{l}\text { "Streptococcus faecalis subsp. li- } \\
\text { quefaciens" Kiel } 26506\end{array}$ & $\mathrm{D}$ & 37.5 & Lys-Ala ${ }_{2-3}$ \\
\hline $\begin{array}{l}\text { "Streptococcus faecalis subsp. zy- } \\
\text { mogenes" Kiel } 20225\end{array}$ & $\mathrm{D}$ & 38.1 & Lys-Ala $2-3$ \\
\hline Streptococcus faecium DSM $20477^{\mathrm{T}}$ & D & 39.0 & Lys-D-Asp \\
\hline Streptococcus faecium DSM 20160 & $\mathrm{D}$ & 37.4 & Lys-D-Asp \\
\hline Streptococcus faecium CCM 2123 & $\mathrm{D}$ & 38.6 & Lys-D-Asp \\
\hline Streptococcus faecium CCM 2308 & $\mathrm{D}$ & 38.1 & Lys-D-Asp \\
\hline Streptococcus faecium CCM 2423 & D & 38.0 & Lys-D-Asp \\
\hline Streptococcus faecium CCM 2424 & $\mathrm{D}$ & 37.5 & Lys-D-Asp \\
\hline Streptococcus faecium Kiel 26352 & $\mathrm{D}$ & 38.3 & Lys-D-Asp \\
\hline Streptococcus lactis DSM $20481^{\mathrm{T}}$ & $\mathrm{N}$ & 36.0 & Lys-D-As \\
\hline Streptococcus mutans ATCC $25175^{\mathrm{T}}$ & & 37.5 & Lys-Ala $2-3$ \\
\hline Streptococcus species Kiel $9938^{b}$ & Q & & Lys-D-Asp \\
\hline $\begin{array}{l}\text { Streptococcus thermophilus DSM } \\
20479\end{array}$ & & 38.3 & Lys-Ala $2-3$ \\
\hline Staphylococcus sciuri ATCC $29062^{\mathrm{T}}$ & & 33.6 & $\begin{array}{l}\text { Lys-Ala- } \\
\text { Gly }_{4-5}\end{array}$ \\
\hline Escherichia coli DSM 30083 & & 51.7 & $\begin{array}{l}\mathrm{m}-\mathrm{A}_{2} \mathrm{pm}- \\
\text { direct }^{c}\end{array}$ \\
\hline
\end{tabular}

${ }^{a} \mathrm{~T}=$ Type strain.

' This strain is closely related to "Streptococcus avium" (M. D.

Collins et al., Int. J. Syst. Bacteriol., in press).

${ }^{c} \mathrm{~m}-\mathrm{A}_{2} \mathrm{pm}$, meso-Diaminopinelic acid.

occurrence of Streptococcus faecium strains that differ genotypically from the type strain has also been reported by Farrow et al. (7).

On the basis of the results presented above and previously $(1-3,5,7,8,10,12,17,18,20,23-25)$, we propose that the species Streptococcus faecalis and Streptococcus faecium be reclassified as members of the genus Enterococcus (ex Thiercelin and Jouhaud) nom.rev. as Enterococcus faecalis comb.nov. and Enterococcus faecium comb.nov., respectively.

Description of the genus Enterococcus (ex Thiercelin and Jouhaud 1903). Enterococcus (En.te.ro.coc'cus. Gr. n. enteron intestine; Gr. n. coccus a grain, berry; M.L. masc. n. Enterococcus intestinal coccus) cells are ovoid, occur singly, in pairs, or in short chains, and are frequently elongated in the direction of the chain. Gram positive. Endospores are not formed. May be motile. Facultatively anaerobic. Optimum growth temperature, ca. $35^{\circ} \mathrm{C}$. Strains grow at 10 and $45^{\circ} \mathrm{C}$. Most strains survive heating at $60^{\circ} \mathrm{C}$ for $30 \mathrm{~min}$. Grow in $6.5 \% \mathrm{NaCl}$ and at $\mathrm{pH}$ 9.6. Hydrolyze pyrrolidonyl- $\beta$ naphthylamide. Chemoorganotrophs. Metabolism fermentative. The predominant end product of glucose fermentation is L-lactic acid. Oxygen or other hydrogen acceptors may alter the end products of carbohydrate metabolism. Hydrogen peroxide may or may not accumulate in the presence of oxygen. Do not contain heme compounds. Benzidine negative and usually catalase negative, but some strains may produce pseudocatalase. Some strains synthesize cytochromes or catalase or both when they are provided with hemin. The minimal nutritional requirements are generally complex. React with group D antisera; some strains also react with group $Q$ antisera.

Some strains possess respiratory quinones (menaquinones or demethylmenaquinones). Long-chain fatty acids are predominantly of the straight-chain saturated or monounsaturated types; some strains produce cyclopropane ring acids.

Peptidoglycan type: Lys-D-Asp or Lys-Ala $2-3$.

The $\mathrm{G}+\mathrm{C}$ content of the DNA ranges from 37 to $45 \mathrm{~mol} \%$.

Type species: Enterococcus faecalis.

Nucleic acid hybridization studies, in particular DNArRNA hybridization studies, demonstrate that members of the genus Enterococcus are closely related to each other but not to members of the genus Streptococcus. Enterococci can easily be differentiated from streptococci by their ability to

TABLE 2. Hybridization between ${ }^{3} \mathrm{H}$-labeled $23 \mathrm{~S}$ rRNAs from Streptococcus faecalis DSM 20376 and "Streptococcus avium" DSM 20063 and filter-bound DNAs from different streptococci and other bacteria

\begin{tabular}{|c|c|c|}
\hline \multirow{2}{*}{ Source of DNA } & \multicolumn{2}{|c|}{$\begin{array}{l}\text { Melting temp }\left({ }^{\circ} \mathrm{C}\right) \text { after } \\
\text { hybridization with }{ }^{3} \mathrm{H} \text {-labeled } \\
\text { rRNA from: }\end{array}$} \\
\hline & $\begin{array}{l}\text { Streptococcus } \\
\text { faecalis } \\
\text { DSM } 20376\end{array}$ & $\begin{array}{l}\text { "Streptococcus } \\
\text { avium" } \\
\text { DSM } 20063\end{array}$ \\
\hline $\begin{array}{l}\text { "Streptococcus faecalis subsp. fae- } \\
\text { calis" DSM } 20376\end{array}$ & 80.0 & $\mathrm{ND}^{a}$ \\
\hline $\begin{array}{l}\text { “Streptococcus faecalis" DSM } \\
20478\end{array}$ & 79.8 & 75.1 \\
\hline $\begin{array}{l}\text { "Streptococcus faecalis subsp. zy- } \\
\text { mogenes" Kiel } 20225\end{array}$ & 79.2 & ND \\
\hline $\begin{array}{l}\text { "Streptococcus faecalis subsp. fae- } \\
\text { calis" Kiel } 7067\end{array}$ & 79.1 & ND \\
\hline $\begin{array}{l}\text { "Streptococcus faecalis subsp. li- } \\
\text { quefaciens" Kiel } 26506\end{array}$ & 78.0 & ND \\
\hline Streptococcus faecium DSM $20477^{\mathrm{T}}$ & 78.0 & 76.7 \\
\hline Streptococcus faecium DSM 20160 & 78.0 & ND \\
\hline Streptococcus faecium CCM 2423 & 77.4 & 77.2 \\
\hline Streptococcus faecium CCM 2424 & 77.4 & ND \\
\hline Streptococcus faecium CCM 2308 & 77.3 & ND \\
\hline $\begin{array}{l}\text { "Streptococcus casseliflavus" } \\
\text { CCM } 2478\end{array}$ & 77.3 & 77.0 \\
\hline "Streptococcus durans" CCM 5612 & 77.1 & ND \\
\hline $\begin{array}{l}\text { "Streptococcus casseliflavus", } \\
\text { CCM } 2479\end{array}$ & 76.6 & 76.3 \\
\hline $\begin{array}{l}\text { Streptococcus species serology } \\
\text { group Q Kiel } 9938\end{array}$ & 76.5 & 79.8 \\
\hline $\begin{array}{l}\text { "Streptococcus faecium" Kiel } \\
26352\end{array}$ & 76.3 & ND \\
\hline “Streptococcus avium”' DSM 20063 & 76.3 & 80.5 \\
\hline "Streptococcus durans"' Kiel 27382 & 75.9 & 74.9 \\
\hline $\begin{array}{l}\text { "Streptococcus faecium" CCM } \\
2123\end{array}$ & 74.6 & ND \\
\hline Streptococcus mutans ATCC $25175^{\mathrm{T}}$ & 71.2 & 69.9 \\
\hline Staphylococcus sciuri ATCC $29062^{\mathrm{T}}$ & 71.0 & 70.5 \\
\hline Streptococcus bovis DSM $20480^{\mathrm{T}}$ & 70.9 & 70.0 \\
\hline $\begin{array}{l}\text { Streptococcus thermophilus DSM } \\
20479\end{array}$ & & 70.5 \\
\hline Streptococcus lactis DSM $20481^{\mathrm{T}}$ & 68.7 & 67.8 \\
\hline Escherichia coli DSM 30083 & 63.4 & \\
\hline
\end{tabular}

${ }^{a}$ ND, Not determined. 


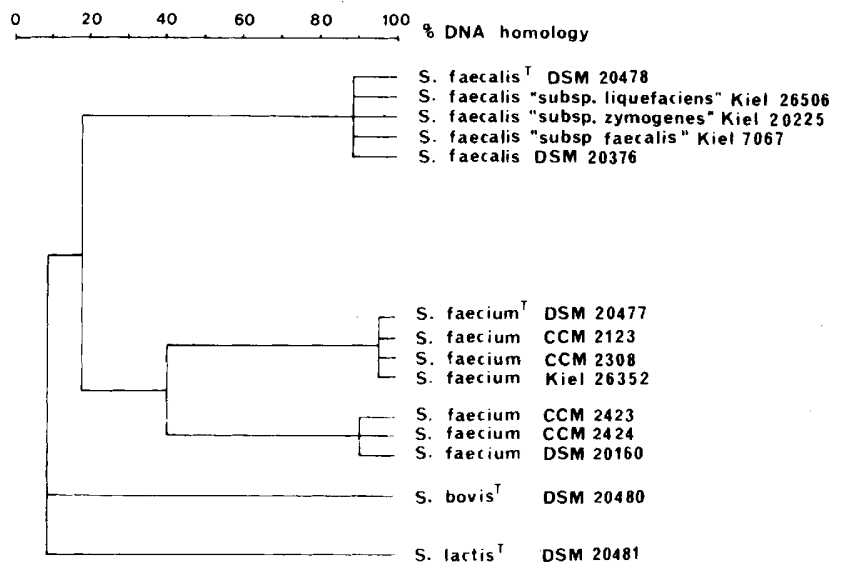

FIG. 1. Dendrogram based on DNA-DNA-homology. DNA hybridization studies were carried out under optimal conditions $\left(25^{\circ} \mathrm{C}\right.$ below the melting point of DNA).

grow in $6.5 \% \mathrm{NaCl}$ and at $\mathrm{pH} 9.6$. Moreover, in contrast to most streptococci (exceptions are Streptococcus lactis, Streptococcus cremoris, and Streptococcus uberis), they can grow at $10^{\circ} \mathrm{C}$.

Description of Enterococcus faecalis (Andrewes and Horder) comb.nov. The following description of Enterococcus faecalis (fae.cal'is. L.n. faex, dregs; N.L.adj. faecalis relating to feces) is based on the description given by Deibel and Seeley (3) and the studies of Schleifer and Kandler (20), Collins and Jones (2), Facklam and Wilkinson (6), Kilpper-Bälz et al. (12), and Farrow et al. (7).

Surface colonies on blood agar or nutrient agar are circular, smooth, and entire. Most strains are nonhemolytic; rarely, strains exhibit $\beta$-hemolysis. Ovoid cells elongated in the direction of the chain occur singly, in pairs, or in short chains. Usually nonmotile; rarely, strains are motile. Strains grow at 10 and $45^{\circ} \mathrm{C}$, survive heating at $60^{\circ} \mathrm{C}$ for $30 \mathrm{~min}$, and grow in $6.5 \% \mathrm{NaCl}$ at $\mathrm{pH} 9.6$ and in $0.1 \%$ methylene blue milk. Acid is produced from glycerol (under aerobic and anaerobic conditions), mannitol, sucrose, trehalose, D-tagatose, ribose, galactose, D-glucose, D-fructose, D-mannose, $\mathrm{N}$-acetylglucosamine, salicin, cellobiose, maltose, lactose, $\beta$-gentiobiose, amygdalin, and arbutin. Acid is not produced from erythritol, D-arabinose, L-arabinose, $\alpha$-methyl-xyloside, inositol, D-fucose, L-fucose, D-xylose, L-xylose, adonitol, L-sorbose, dulcitol, $\alpha$-methyl-D-mannoside, $\alpha$-methyl-Dglucoside, melibiose, inulin, D-raffinose, glycogen, xylitol, D-turanose, D-lyxose, D-arabitol, L-arabitol, and 5-ketogluconate. Acid may be produced from rhamnose, sorbitol, melezitose, amidon, gluconate, and 2-keto-gluconate. The final $\mathrm{pH}$ in glucose broth is between 4.1 and 4.6.

Pyruvate is utilized as an energy source, as are citrate, malate, and serine. The utilization of the latter three substances is linked to pyruvate metabolism. Utilization of pyruvate, citrate, malate, and serine requires lipoate. Arginine and often agmatine are also utilized as energy sources. Strains do not require folic acid for growth in semidefined media.

Some strains produce a pseudocatalase. When grown aerobically, some strains possess a potent peroxidase and consequently do not accumulate hydrogen peroxide.

Growth occurs in the presence of $0.04 \%$ tellurite, which is reduced to tellurium, and in the presence of $0.01 \%$ tetrazolium, which is reduced to formazan. Growth occurs in the presence of $0.1 \%$ thallous acetate and $0.02 \%$ sodium azide.
Most strains decarboxylate tyrosine to tyramine plus carbon dioxide. Some strains hydrolyze gelatin, and some strains produce hyaluronidase. Most strains hydrolyze hippurate and esculin. Starch is not hydrolyzed.

The peptidoglycan type is Lys- $\operatorname{Ala}_{2-3}(10,12,20)$. The group-specific antigenic determinant (Lancefield group D) is a lipoteichoic acid in which glycerol residues are substituted with glucose and a D-alanine residue is linked to glucose (27, 28).

Most strains contain demethylmenaquinones with nine isoprene units as their major isoprenologs (2). Hexadecanoic, octodecenoic, and cis-11,12-methylenoctadecanoic acids are the major fatty acids.

The $\mathrm{G}+\mathrm{C}$ content of the DNA ranges from 37 to $40 \mathrm{~mol} \%$.

The type strain is strain ATCC 19433 (= NCTC $775=$ NCDO 581 = DSM 20478).

Description of Enterococcus faecium (Orla-Jensen) comb. nov. The following description of Enterococcus faecium (fae'ci.um. L.n. faex, dregs; L.gen.pl.n. faecium of the dregs, of feces) is based on the description given by Deibel and Seeley (3) and the studies of Schleifer and Kandler (20), Collins and Jones (2), Kilpper-Bälz et al. (12), and Farrow et al. (7).

Surface colonies on blood agar or nutrient agar are circular, smooth, and entire. Nonpigmented. Some strains may produce an alpha-reaction on blood agar. Ovoid cells, elongated in the direction of the chain, occur chiefly in pairs or short chains. Some strains are motile. Strains grow at 10 and $50^{\circ} \mathrm{C}$, survive heating at $60^{\circ} \mathrm{C}$ for $30 \mathrm{~min}$, and grow in $6.5 \%$ $\mathrm{NaCl}$ and at $\mathrm{pH}$ 9.6. Acid is produced from ribose, galactose, D-glucose, D-fructose, D-mannose, $N$-acetylglucosamine, amygdalin, arbutin, salicin, cellobiose, maltose, lactose, $\beta$ gentiobiose, glycerol (only under aerobic conditions), Larabinose, and trehalose. Acid is not produced from Dxylose, L-xylose, adonitol, L-sorbose, rhamnose, dulcitol, sorbitol, $\alpha$-methyl-D-glucoside, inulin, melezitose, D-raffinose, amidon, glycogen, xylitol, D-turanose, D-lyxose, Dtagatose, D-arabitol, L-arabitol, 2-keto-gluconate, 5-ketogluconate, erythritol, D-arabinose, $\alpha$-methyl-xyloside, inositol, D-fucose, and L-fucose. Acid may be produced from mannitol, $\alpha$-methyl-D-mannoside, melibiose, sucrose, and gluconate. The final $\mathrm{pH}$ in glucose broth is 4.0 to 4.4 .

Pyruvate, citrate, malate; and serine are not utilized as sources of energy for growth. Ammonia is produced from arginine, but it is not used as an energy source. Hippurate and esculin are hydrolyzed. Gelatin is not hydrolyzed. Hydrogen peroxide may accumulate in the presence of oxygen.

TABLE 3. Differentiation of Enterococcus fáecalis and Enterococcus faecium

\begin{tabular}{|c|c|c|}
\hline Characteristic & Enterococcus faecalis & Enterococcus faecium \\
\hline Peptidoglycan type & Lys-Ala ${ }_{2-j}$ & Lys-D-Asp \\
\hline Menaquinones & DMK-9 & - \\
\hline \multicolumn{3}{|l|}{ Acid produced from: } \\
\hline Arabinose & - & + \\
\hline Tagatose & + & - \\
\hline \multicolumn{3}{|l|}{ Energy from: } \\
\hline Pyruvate & + & - \\
\hline Citrate & + & - \\
\hline Malate & + & - \\
\hline Serine & + & - \\
\hline \multicolumn{3}{|l|}{ Reduction of: } \\
\hline $0.04 \%$ Tellurite & + & - \\
\hline $0.01 \%$ Tetrazolium & + & - \\
\hline
\end{tabular}


Growth occurs in the presence of $0.1 \%$ thallous acetate and $0.02 \%$ sodium azide. Tellurite $(0.04 \%)$ is not reduced to tellurium, nor is tetrazolium $(0.01 \%)$ reduced to formazan.

The peptidoglycan type is Lys-D-Asp $(10,12,20)$. Cells contain neither menaquinones nor ubiquinones (2). Hexadecanoic, octadecenoic, and cis-11,12-methylenoctadecanoic acids are the major fatty acids (7).

The $\mathrm{G}+\mathrm{C}$ content of the DNA ranges from 37 to $40 \mathrm{~mol} \%$.

The type strain is strain ATCC $19434(=$ NCTC $7171=$ NCDO 942 = DSM 20477).

The differential characteristics of the two species described above are listed in Table 3.

\section{ACKNOWLEDGMENTS}

This work was supported by a grant of Deutsche Forschungsgemeinschaft.

We are indebted to $\mathrm{D}$. Jones for revising the manuscript.

\section{LITERATURE CITED}

1. Bridge, P. D., and P. H. A. Sneath. 1983. Numerical taxonomy of Staphylococcus. J. Gen. Microbiol. 129:565-597.

2. Collins, M. D., and D. Jones. 1979. The distribution of isoprenoid quinones in streptococci of serological groups D and N. J. Gen. Microbiol. 114:27-33.

3. Deibel, R. H., and H. W. Seeley, Jr. 1974. Streptococcus Rosenbach 1884, p. 490-509. In R. E. Buchanan and N. E. Gibbons (ed.), Bergey's manual of determinative bacteriology, 8 th ed. The Williams \& Wilkins Co., Baltimore.

4. De Ley, J. 1970. Reexamination of the association between meiting point, buoyant density, and chemical base composition of deoxyribonucleic acid. J. Bacteriol. 101:738-754.

5. Facklam, R. R., L. G. Thacker, B. Fox, and K. Eriquez. 1982. Presumptive identification of streptococci with a new test system. J. Clin. Microbiol. 15:987-990.

6. Facklam, R. R., and H. W. Wilkinson. 1981. The family Streptococcaceae (medical aspects), p. 1572-1597. In M. P. Starr, H. Stolp, H. G. Trüper, A. Balows, and H. G. Schlegel (ed.), the prokaryotes, vol. 2. Springer-Verlag, Berlin.

7. Farrow, J. A. E., D. Jones, B. A. Phillips, and M. D. Collins. 1983. Taxonomic studies on some group D streptococci. J. Gen. Microbiol. 129:1423-1432.

8. Jones, D. 1978. Composition and differentiation of the genus Streptococcus, p. 1-49. In F. A. Skinner and L. B. Quesnel (ed.), Streptococci. Academic Press, Inc., London.

9. Kalina, A. P. 1970. The taxonomy and nomenclature of enterococci. Int. J. Syst. Bacteriol. 20:185-189.

10. Kandler, O., K. H. Schleifer, and R. Dandl. 1968. Differentiation of Streptococcus faecalis Andrewes and Horder and Streptococcus faecium Orla-Jensen based on the amino acid composition of their murein. J. Bacteriol. 96:1935-1939.
11. Kilpper, R., U. Buhl, and K. H. Schleifer. 1980. Nucleic acid homology studies between Peptococcus saccharolyticus and various anaerobic and facultative anaerobic Gram-positive cocci. FEMS Microbiol. Lett. 8:205-210.

12. Kilpper-Bälz, R., G. Fischer, and K. H. Schleifer. 1982. Nucleic acid hybridization of group $\mathrm{N}$ and group D streptococci. Curr. Microbiol. 7:245-250.

13. Kilpper-Bälz, R., and K. H. Schleifer. 1981. DNA-rRNA hybridization studies among staphylococci and some other Grampositive bacteria. FEMS Microbiol. Lett. 10:357-362.

14. London, J., N. Chace, and K. Kline. 1975. Aldolase of lactic acid bacteria: immunological relationships among aldolases of streptococci and gram-positive nonsporing anaerobes. Int. J. Syst. Bacteriol. 25:114-123.

15. London, J., and K. Kline. 1973. Aldolase of lactic acid bacteria: a case history in the use of an enzyme as an evolutionary marker. Bacteriol. Rev. 37:453-478.

16. Marmur, J., and P. Doty. 1962. Determination of the base composition of deoxyribonucleic acid from its thermal denaturation temperature. J. Mol. Biol. 4:109-118.

17. Ritchey, T. W., and H. W. Seeley, Jr. 1974. Cytochromes in Streptococcus faecalis var. zymogenes grown in haematincontaining medium. J. Gen. Microbiol. 85:220-228.

18. Ritchey, T. W., and H. W. Seeley, Jr. 1976. Distribution of cytochrome-like respiration in streptococci. J. Gen. Microbiol. 93:195-203.

19. Schleifer, K. H., and O. Kandler. 1967. Zur chemischen Zusammensetzung der Zellwand der Streptokokken. I. Die Aminosäuresequenz des Mureins von Str. thermophilus und Str. faecalis. Arch. Mikrobiol. 57:335-364.

20. Schleifer, K. H., and O. Kandler. 1972. Peptidoglycan types of bacterial cell walls and their taxonomic implications. Bacteriol. Rev. 36:407-477.

21. Sherman, J. M. 1937. The streptococci. Bacteriol. Rev. 1:3-97.

22. Thiercelin, E., and L. Jouhaud. 1903. Reproduction de l'enterocoque: taches centrales; granulations peripheriques et microblastes. C. R. Seances Soc. Biol. Paris 55:686-688.

23. Whittenbury, R. 1964. Hydrogen peroxide formation and catalase activity in lactic acid bacteria. J. Gen. Microbiol. 35:13-26.

24. Whittenbury, R. 1965. The differentiation of Streptococcus faecalis and Streptococcus faecium. J. Gen. Microbiol. 38:279287.

25. Whittenbury, R. 1965. A study of some pediococci and their relationship to Aerococcus viridans and the enterococci. J. Gen. Microbiol. 40:97-106.

26. Whittenbury, R. 1978. Biochemical characteristics of Streptococcus species, p. 51-69. In F. A. Skinner and L. B. Quesnel (ed.), Streptococci. Academic Press, Inc., London.

27. Wicken, A. J., and J. Baddiley. 1963. Structure of intracellular teichoic acids from group D streptococci. Biochem. J. 87:54-62.

28. Wicken, A. J., S. D. Elliot, and J. Baddiley. 1963. The identity of streptococcal group D antigen with teichoic acid. J. Gen. Microbiol. 31:231-239. 